\title{
"Away from Here to Tjottahejti": Spatial and Sexual (Re-)Orientation in Places of Secondariness in Contemporary Swedish Fiction
}

\author{
Sophie Wennerscheid
}

Places of secondariness-marginalized suburbs with large-scale housing areas, boring small towns and sparsely populated rural areas-have become an a frequent topic of in contemporary Swedish literature. The subject first became popular in 1970s young adult books, declined in significance in the subsequent decades, but reappeared onto the agenda at the end of the twentieth century. An initial impulse for this reorientation and revaluation came in 1994, when the Swedish hip-hop band The Latin Kings released their debut album Välkommen till förorten ("Welcome to the suburbs"). With roots in Latin America but raised in Botkyrka, a suburb of Stockholm, the group's members drew attention to the often-overlooked non-heritage Swedes, also called "new Swedes," and their places of living: chiefly suburbs consisting of blocks of flats.

S. Wennerscheid $(\square)$

Faculty of Arts and Philosophy, Ghent University,

Ghent, Belgium

e-mail: sophie.wennerscheid@ugent.be

(C) The Author(s) 2017

J. Finch et al. (eds.), Literary Second Cities,

DOI 10.1007/978-3-319-62719-9_10 
In contrast to the general characterization of the inner city as the centre and the suburbs as the urban outskirts, The Latin Kings reversed the perspective and invited their audience to have a closer look at these places of secondariness "where the People's Home never made it" (Ernst 133). ${ }^{1}$ In the song "Botkyrka Stylee" from The Latin Kings' second album, I skuggan av betongen ("In the concrete shade," 1997), the lead rapper Dogge Doggelito announced the group's artistic credo as follows:

We're representing the suburbs' voice in style

We're telling the story of our everyday life like a safety valve

My aggression comes out through strong words

With rhythm in my blood

Although we live in northern Botkyrka

We can locate our home on the map. (Latin Kings 47-48)

As a result, in recent years increasing attention has been paid to formerly neglected places in Sweden, which have now, as the film scholar Anna Westerståhl Stenport argues, become "considered as worthy screen locations" (86). Literary or cinematic suburbs and small towns are, however, still used in a very particular way, namely as settings in which young adult protagonists have to find their own mode of living in precarious social circumstances. In this context, the suburb is often regarded as an especially hostile environment, as somewhere which makes it hard for young people to develop a feeling of home and security. Drawing on Sara Ahmed's notion of the "body not at home," these protagonists can be characterized as disoriented and uprooted young people, who are desperate to escape their cramped living conditions and make their way to a "first city"-within the Swedish context typically Stockholm or Gothenburg-or to a utopian, even imaginary, place which offers the vague promise of a better living. "Away from here to Tjottahejti" (244), as the young protagonist Miira in Eija Hetekivi Olsson's novel Ingenbarnsland "No Children's Land," 2012 ) puts it.

These kinds of experiences, often negotiated in contemporary initiation or education novels, appear to be near-universal at first glance. On closer examination, however, some characteristics, resulting from geographical and temporal specificity, come forth. One of these particularities which I want to explore in more detail in this chapter is the critical stance many contemporary Swedish novels take on the Swedish welfare 
society of the 1970s. This critical position finds its clearest expression in the way the Swedish public housing programme known as the Million Programme (Miljonprogrammet), implemented in the 1960s and 1970s, is discussed in the novels in question. It is seen as resulting in housing estates that were experienced as places for second-class citizens: desolate and inhospitable locations constraining individual personality development-in a nutshell, places of secondariness.

In examining the literary negotiations of these desolate places of secondariness the approach I want to apply is a critical phenomenological one. Such an approach makes it possible to examine the places in question as they are experienced by those who inhabit them: young people with often difficult social, economic and ethnic backgrounds. One example is Hetekivi Olsson's Miira, mentioned above. When fifteen-year-old Miira examines the class photo in the recent school catalogue to figure out who among the pupils might be Swedish and who might be Finnish, she is very confident of her judgement. Her certainty is grounded in obvious similarities her Finnish classmates, herself included, share with one another. The Finnish pupils are those who "look a bit filthier than the others, their bodies stiffer, their mouths more closed and their smile tighter. Their posture more stooped" (207). The differences between Swedish and Finnish pupils, however, are not primarily markers of nationality but of class. According to the third-person narrator, who very often takes Miira's perspective, the photo is "the visual proof of class affiliation" (207). Class is clearly marked and identifiable here as an embodied and place-bound feature. It is inscribed in the Finnish pupils' bodies, which are day by day pushed around in a run-down Swedish suburb, which has become part of their precarious identity.

The aim of my chapter is to examine further the interconnectedness of urban living environments, bodily materializations and identity formation. Since factors such as how and where one lives do not only affect class identity but also sexual identity, special attention will be paid to the question of how spatial and sexual orientations are related. Beside Hetekivi Olsson's novel my corpus includes Lukas Moodysson's movie Fucking Amail (Show Me Love, 1998), and the following novels: Lena Andersson's Var det bra så? ("Was it OK?", 1999), Johan Ejvide Lindqvist's Lait den rätte komma in (Let the Right One In, 2004), Susanna Alakoski's Svinalängorna ("The pigsties," 2006) and Mikael Niemi's Skjut apelsinen ("Shoot the orange," 2010). ${ }^{2}$ 
To analyse processes of spatial and bodily formation in detail, I will first reflect on Merleau-Ponty's concept of "bodily space" and Sara Ahmed's reflections on "being (not) at home" and "sexual/spatial (re) orientation." In the second section I will give some background information on the Swedish housing programme and examine how it is presented in my filmic and literary examples. In section three I will expand on those presentations by focusing on the literary second city as the bodily experienced city. In the fourth and final section special attention is given to spatial and sexual (re-)orientations.

\section{Body and Place: Phenomenological Approaches}

The role the urban environment plays in identity formation is a topic broadly discussed in human geography and literary urban studies. The main questions here are: How do place and body interact? How does the body inhabit a specific place? How is it shaped by this place, and how is the place transformed by the body? One of the theorists to have inspired phenomenologically-informed urban studies in a significant way is Maurice Merleau-Ponty. In his renowned work Phenomenology of Perception (1945), Merleau-Ponty develops the idea of the body as the primary site of knowing the world. He regards the world not as an unchanging object exterior to us but instead as a correlate of our body. As the subject perceives the world, not only does the subject develop, but also the world transforms. Perception thus is not a passive act but has an active dimension. As a perceiving subject, the body is defined as "being-in-the-world," a concept Merleau-Ponty borrowed from Martin Heidegger (El-Bizri).

In the chapter titled "The Spatiality of One's Own Body and Motility" (100-48), Merleau-Ponty addresses the fundamental relations between body and space. Here, he distinguishes between "bodily space" or "oriented space" on the one hand, and "objective space" on the other (103). With objective space, Merleau-Ponty refers to an empiricist understanding of the world as something fixed and determined, as something external to human subjects. Bodily space, by contrast, is a term coined by Merleau-Ponty to describe space as coexistent with the body. The body is not a body in space, but a body of space, a body always orientated towards space, tied to space, inhabiting space. And consequently, space is always space inhabited by the body. Henri Lefebvre's concept of lived space, as presented in his book The Production of Space (1974), might come to mind here as well. While the concept of conceived space 
in Lefebvre's theory refers to a mental construction, an idea of space employed by urban designers and others, and the concept of perceived space, in contrast, embraces the notion of social practices, the concept of lived space combines these two concepts and denotes the space of subjectivity.

Merleau-Ponty's thoughts on being as something essentially spatial also had an important impact on various architects. From the early 1990s onwards, a strong interest "in sensory connections between the building and the individual experiencing subject" emerged, as Jonathan Hale puts it in his article on "Critical Phenomenology: Architecture and Embodiment" (22). Particularly important for this tendency was the Finnish architect Juhani Pallasmaa whose book The Eyes of the Skin, first published in 1996, has become a classic of architectural theory. In his book, Pallasmaa criticizes the "sensory reductivism" (32) that prevails in modern Western culture. The dominance of vision over the other senses, Pallasmaa argues, results in neglect of the body and sensory detachment from our built environment. He even goes so far as to say that modern(ist) architecture, privileging vision as much as it does, leaves the body "homeless" (22). In his own architecture, Pallasmaa thus puts an emphasis on the spatial experience of a building and tries to take into account "the tacit wisdom of the body" (28). In my literary corpus, this kind of critique of modernist architecture re-emerges.

Another crucial aspect for my interest in individually experienced urban places is the social dimension of the urban environment. MerleauPonty had already highlighted what later became a central issue for many urban theorists, namely that the space the body is oriented to is not a neutral but a socially encoded space. Merleau-Ponty points out:

The social world is already there when we come to know it or when we judge it. An individualistic or sociological philosophy is a certain perception of coexistence systematized and made explicit. Prior to this coming to awareness, the social exists silently and as a solicitation. (379)

To experience the world, or more precisely a concrete place, thus means to experience a place already structured by preconceived categories, by traditions, norms and values. In Spatial Politics in Contemporary London Literature: Writing Architecture and the Body (2013), the literary urban studies scholar Laura Colombino further discusses the ethical and sociopolitical dimension of urban space. She stresses that a city is not to be 
regarded as an ahistorically friendly place to dwell in, but as a place built by people with specific interests, possibly hostile to or ignorant of other peoples' needs and wishes. Such antagonistic interests cause social struggles, which in turn are reproduced internally by the city dwellers. According to Colombino, spatial materializations of socio-political conditions therefore shape the concept of the urban self. It is "an embodied practice performed at the point where the built environment and the body enter into a relation with each other" (1).

Hana Wirth-Nesher, in City Codes: Reading the Modern Urban Novel (1996), also expresses scepticism about a universalistic description of cityscapes and emphasizes that the representation of the city depends on the cultural and social position of the particular city-dweller (4-8), be it a "real one" or a city-dwelling character in a novel. The same feature of a city, for example a well-known landmark, can signify very different things to different persons. The key point, both for Wirth-Nesher and for my own approach, is thus the urbanites' affects that are linked to specific urban places. This aspect is crucial as it can be directly linked to Sara Ahmed's critical phenomenological approach which focuses on bodies as effects of social encounters that inscribe into the body or give the body a "second skin."

In the introduction to the volume Thinking Through the Skin (2001), Ahmed and Jackie Stacey describe skin as "fleshy interface between bodies and worlds" (1). ${ }^{3}$ In her book Queer Phenomenology, Ahmed further characterizes skin as a body's surface that connects it with the place it dwells in: "the skin that seems to contain the body is also where the atmosphere creates an impression" (9). Since places impress on or inscribe into bodies, they are "not exterior to bodies; instead, spaces are like a second skin that unfolds in the folds of the body" (9). The second skin, shaped by the concrete experience of the second city, is thus to be understood as a social skin; it is a skin that connects the individual with his or her social surroundings. When the skin is, as seen in the abovementioned quotation from Ingenbarnsland, a skin the body does not feel comfortable in, making it feel inferior to other bodies more at home in the world, the skin is marked in a negative, self-deprecating way. In accordance with Frantz Fanon, such a process can be called "internalization or rather the epidermalization of . . inferiority" (15).

Another aspect stressed by Ahmed is the body's positioning or orientation in the world. The point where we are and look at things makes things appear in a specific way, and is our starting point for being 
oriented in the world. In her article "Phenomenology of Whiteness," Ahmed points out that what "comes into view, or what is within our horizon" is not the result of happenstance but determined by "orientations we have already taken" (152): the place we are born into, and the way we are placed and positioned into it, as also stated by MerleauPonty, pre-exist our agency. Simply put: a white middle-class girl is positioned differently, sees things differently and is seen differently than, for example, a non-white working-class boy, who, due to his "otherness," is not simply "at home in the world."

In the same article, Ahmed expands on the specific living conditions of people who inhabit "a white world as a non-white body" (149), where "non-white" is not to be understood exclusively as a category of skin colour but implies various forms of being different: of being disadvantaged, dislocated or misrecognized. Such a non-white body, Ahmed stresses by citing Frantz Fanon, is "surrounded by an atmosphere of certain uncertainty" (qtd. in "Phenomenology" 152), and thus does not feel at home in the world. While white people are at home in "a world that is orientated around whiteness" (160), non-white people experience themselves as being out of place.

As non-white bodies feel uncomfortable in a white world, bodies desiring bodies of the same sex feel unfamiliar in a heterosexually coded world. Exploring the aspect of spatiality more deeply, Ahmed calls attention to the point that sexual orientation is highly influenced by spatial orientation. Spatial orientations affect what and who comes into view. Consequently, bodies take shape as they move through places, directing themselves toward objects and people nearby. Instead of seeing sexual desire as something essential and inborn, Ahmed regards inclinations of desire as formed by how one inhabits space. Growing up with heterosexuality as norm, one tends to be orientated toward heterosexual people. To break this norm, re-orientation is necessary.

Re-orientation, however, does not happen out of the blue. To come into contact with non-heterosexual people and to get oriented towards them requires a specific "contact zone." In Queer Phenomenology, Ahmed underlines that the homosexual, or more specifically the lesbian, is in need of "a space in which the lesbian body can extend itself, as a body that gets near other bodies, which tends towards others who are alike only insofar as they also deviate and pervert the lines of desire" (105). Following Ahmed, inclining away from the norm enables new experiences, sexual as well as urban ones, but does not necessarily provide 
pleasant sensations. Quite the contrary, new affective contacts initiating queer movements disrupt and trouble the established social order. Deviating from the paths one is supposed to follow will probably cause a feeling of disorientation and confusion. Drawing on Merleau-Ponty, Ahmed points out that disorientation does not only involve "the intellectual experience of disorder, but the vital experience of giddiness and nausea" (qtd. in Queer Phenomenology 4).

While Ahmed does not take the issue of small or big cities into consideration but is more engaged with places in general, many LGBT scholars have examined in detail the close connection between urban life and homosexuality. In Metropolitan Lovers (2009), for instance, Julie Abraham has analysed literary depictions of gay city life and shown how homosexuals helped write the modern city. On the other hand, in her study In a Queer Time and Place (2005), Judith Halberstam points out that "the essential characterization of queer life as urban" (15) is shortsighted. In accordance with this argument, my analysis of the literary texts chosen for this study will show that "queering the (Swedish) small town" (Björklund) is an option at least to some of the protagonists in question. So, how are the bodies negotiated that are part of the Swedish "People's Home," but nevertheless are marked by a feeling of notbelonging, of being not at home?

\section{The Body not at Home in the Swedish People's Home}

The concept of the second city, or more generally of places that are perceived as secondary, marginalized and neglected, is especially interesting when we examine contemporary Swedish (sub)urban narratives. Numerous of these narratives are set in the 1970s and 1980s and refer at least implicitly to the imaginary of the so-called Swedish People's Home. The metaphorical use of the notion of the home can be traced back to Per Albin Hansson, chairman of the Social Democrats from 1925, who used and coined the well-known metaphor of the People's Home (folkhemmet) to illustrate his political vision of society. This, according to him, ought to be like a good home or like a family where everybody is included on equal terms. In a famous parliamentary speech made in early 1928, Hansson presented his idea of a classless society as follows:

Applied to the great people's and citizens' home ["folk- och medborgarhemmet"] this would mean the breaking down of all the social and 
economic barriers that now separate citizens into the privileged and the neglected, into the rulers and the dependents, into the rich and the poor, the propertied and the impoverished, the plunderers and the plundered. (qtd in Tilton 126)

The notion of the People's Home, which is a highly complex and controversial issue, has been crucial for Swedish self-understanding over decades and is in the 2010s still indispensable to public discourse about the Swedish welfare model. As an important part of this welfare model, the Swedish social-democratic government of the 1960s and 1970s took up Hansson's vision and, alongside other reforms, began the Million Programme. This scheme worked towards a target of building one million new homes in ten years to provide decent standard housing for all Swedes. Although the Million Programme succeeded in reducing overcrowding and generally improving living standards, it has encountered repeated and severe criticism. By the end of the 1960s critical voices were already being raised. These "drew attention to all the shortcomings that were now quickly associated with the apartment blocks of the 'record years': visual monotony, a desolate external environment, lack of local service and transport, alienation and isolation" (Hall and Vidén 303). During the early 1970s, the project was seriously questioned in the media. The new multi-dwelling complexes, mostly located in the big cities' suburbs, had turned into shabby places for low-waged workers, immigrants and single mothers and were now conceived of as unattractive large-scale concrete housing areas with big social problems.

While some scholars point out that despite obvious deficits the situation in the marginalized housing areas "is often much better than the rumour suggests" (Castell 18), others express a more fundamental scepticism. For them, housing segregation is a basic societal problem, depicting Sweden as a racialized and classed society. One scholar who has explored the relation between race and space systematically is Irene Molina. In her ground-breaking work Stadens rasifiering ("Racialization of the city"), she explores racialized residential patterns in Sweden's urban structure and traces them back to lasting racial patterns in the People's Home ideology. She argues that the Swedish People's Home was planned and conceived of as a Swedish People's Home from the very beginning. It was meant for ethnic Swedes and was to include neither national minorities nor immigrants. Following Sara Ahmed, the Swedish People's Home could therefore be called the white people's home. 
And as a white people's home it is a home in which many non-white people feel uncomfortable. They feel like bodies not at home.

And it is precisely such "bodies not at home" that remain central in many literary examples published in recent years. In these texts, the Swedish welfare system, and particularly Swedish urban planning, are considered unsocial and segregating. However, it is interesting to see that this kind of general criticism is often expressed by an authorial narrator's voice, which conveys a more general picture of bad suburban living conditions than do the protagonists themselves. The most obvious example can be found in Lena Andersson's Var det bra så?, set in an imaginary suburb called Stensby ("Stone-village"). The book begins with a prologue that takes the form of a fictional news broadcast:

And now domestic news. The residential areas in Stensby north-west of Stockholm are toxic. As confirmed in a report by the Department of Environment. The joints and walls of the houses built at the end of the sixties and at the beginning of the seventies were sealed with the previously untested substance apatix violencix- $2 / 3$ which was cheaper than other sealing agents. (5)

The newsreader continues to explain the toxic effect of this sealing agent. It is said to cause a disease, called "apatia violencia," the symptoms of which include an "inclination to violence in combination with indifference to democratic values" (5). With this description that generalizes the housing situation in a Swedish 1970s suburban settlement, Andersson follows the well-known cliché about socially disadvantaged suburban neighbourhoods where people neither care for each other nor for their environment but are prone to violence.

In the first chapter, the novel continues with an external narrator who imitates the perspective of an abstract "we" presenting the Social Democrats" housing programme of the late 1960s: "Here on this plain, around the medieval church, shall it be built. The houses should be tall and long, providing space for many people. And things must go quickly. No longer cramped housing conditions, and no more humiliation. We care for our people" (9). This passage very clearly depicts a basic ambivalence which the building programme is very often criticized for: the ambivalence between the proclaimed wish to improve the people's living conditions on the one hand and pragmatic efficiency thinking on the other hand.

This ambivalence can also be seen at the beginning of Johan Ajvide Lindqvist's vampire fiction novel Låt den rätte komma in, set in an 
imaginary Blackeberg with clear references to the real Blackeberg, a working-class suburb of Stockholm:

Blackeberg. One might think of coconut balls, might think of dope. "A decent life." Think metro, suburb. Then again, one might not think of anything else. People can live here, just as they can elsewhere. That's what this place was built for, for people having a place to live in. (7)

The mentioning of "coconut balls" gives a concrete reference to the real Blackeberg's popular candy store, Lincals Konfektyr, where, since the city's founding in the 1950s, coconut balls have been produced. But by alluding to drugs, metro stations and people living in an obviously unexciting environment, the narrator characterizes the suburb as looking like any one of a number of other Swedish suburbs resulting from the Swedish system of urban planning. The authorial narrator continues by taking a clear critical stance towards Swedish housing politics: "No naturally grown place, no. From the very beginning everything was organized in units here. People had to move into something pre-existing. Concrete houses in earth tones, thrown out into the green" (7). The narrator depicts Swedish housing policy as unconcerned and unfeeling. Planning and building houses for a lot of people is obviously no affair of the heart but purely a matter of duty. People need to live somewhere, thus the municipality needs to build something. The results are prefabricated and standardized houses which all look the same.

The third example is taken from Lukas Moodyson's screenplay of his film Fucking Amål, telling the story of two teenage girls falling in love in the stiflingly oppressive small town Åmål. Similarly to the Blackeberg example, this Åmål is a town with a clear reference to the real Åmål, a locality in Västra Götaland County, Sweden. In the script, the residential area, which is home to one of the main characters, Elin, is described as follows:

The blocks are built in the late 1960s. It is a district where less wealthy people live. Even though Åmål is such a small town (the municipality has 13,500 inhabitants) there is a certain level of housing segregation. But the gaps are of course not as wide as in a big city. (Moodysson 4)

The film's setting thus evokes the near-universal complaint against massproduced suburban housing as we already have seen in the previous examples. In her study of Moodysson's film, Stenport emphasizes that 
the area Elin lives in "looks like it could be ... anywhere in contemporary northwestern Europe-the apartment buildings, the standard highway overpass, and the nondescript school are completely anonymous" (91). The city is a generic city, a city without any specific brand. Stenport further elaborates on this by referring to Erik Hedling, who has argued that Fucking Amål, in the legacy of Bergman's films, is representative of landscape construction in "post-utopian European cinema" (190).

With regard to the 1960s Swedish housing programme, it is interesting to notice that Hedling describes Moodysson's film as set against "a backdrop of drab landscapes and extremely ugly 1960s city-scapes" (191). The depiction of the cinematic Åmal's urban landscape as "extremely ugly" is clear hyperbole; it obviously tells more about the image of the Swedish building programme, and of Åmål as a generic town, than about Moodysson's concrete representation of the place as inhabited by its teenager characters. How these individualized representations of the urban places in question look will be examined in the following section.

\section{The Literary Second City as the Bodily EXPERIENCED CITY}

The auctorial narrators reflected on above give a distanced and thus quite general view of the city. They all use descriptive references to the Swedish housing politics of the 1960s and 1970s without giving any further explanation of the Million Programme. They can assume that the Swedish readers will get the point. When, however, the auctorial narrator adopts the perspective of the young protagonists, or when we have a first-person narrator from the beginning, the picture of the locality is much more subjective and nuanced. Although it is not necessarily brighter, it is a picture that shows us the personally experienced urban environment as an environment which affects and shapes the body.

In Andersson's Var det bra så?, the narrator, after having presented his more general description, merges with the story's protagonist, the girl Lena, who is picked up from kindergarten by her mother to bring her back home. Through Lena's senses, the reader comes to know the smells of the Swedish small town or suburb. Even if the housing area is still new, built only four years ago, it already smells stuffy: "The courtyard is sticky and smells like roasted meatballs and deep frying fat, maize, onions and caraway. It's disgusting. The air stands still" (9). The narrator does 
not elaborate on the architecture, but what he says, from Leena's perspective, is enough to evoke the image of a densely built housing area with small and narrow courtyards. Even if no people are mentioned, they are present in the different smells, indicating a multicultural neighbourhood. Images of tightness, stuffiness and the feeling of crowdedness are conjured up in the reader's mind.

In Susanna Alakoski's Svinalängorna, it is not the urban environment's smell that is highlighted at the beginning of the novel, but rather its haptic quality. When the novel's central family, the family Moilanen, visits their new apartment, located in a residential neighbourhood called Fridhem ("Peace home") for the first time, the mother appropriates the apartment with her whole body. She has a look into every single room and also into every niche and corner. She opens the empty kitchen cabinets, turns on the water tap, knocks on the walls and runs her fingers over the furniture. She familiarizes herself with the apartment by touching it (13-14).

The mother's narrowed view on how the new apartment looks from inside is widened through the perspective of her daughter Leena, who is introduced as the novel's first-person narrator. Leena surveys not just the apartment but also the whole neighbourhood. The city district Leena lives in is characterized by two principal building materials: asphalt and concrete. While the mother is only worried about the concrete walls of the family's flat because it is difficult to hammer nails into them, Leena's focus is broader. She implicitly recognizes that the omnipresent asphalt will have an impact on the quality of life. The sensory reduction, as Pallasmaa would have called it, threatens to make her life monotonous. But Leena's perception is not that black and white. The urban places she comes into contact with, affect her in different ways. She finds nuances even in asphalt. "The asphalt under the swings was hot and smelled new. In the yard it was soft and blue black, and on the footpath it was hard and greyish black." (19)

Another part of Leena's experience of her environment is what she hears: the neighbourhood's noise. After she and her family have been living in Fridhem for one year, the place is very crowded, with too many people packed together in too small a place.

Upstairs Bagar Olsson moved in. He played Elvis songs when he boozed . . . Next door lived a Polish family. Above them lived a mum with her child. In the other staircase lived another mum with her child. Everywhere lived mums 
and dads and children. Fridhem had become packed, my mum said . . People came and people left, the front door was slammed and the lid of the waste bin was opened and banged all the time. (Alakoski 26)

People play music too loudly and they slam the doors. They behave in an inconsiderate manner. But the real cause for the noise is not the people's behaviour but what it is caused by. Since the apartments are cheaply built they are badly soundproofed, and since they are too small for low income families who cannot afford more spacious places, people are forced to go outside. Thus, a noisy atmosphere is the natural consequence.

A third characteristic, like in Andersson's Var det bra så?, is the neighbourhood's stench. As the neighbourhood's nickname, pigsties, indicates, Leena's urban environment is denigrated as a malodorous and messy place. Little Leena does not describe her neighbourhood's smell directly but in comparison with one of the better residential areas she happens to visit one day: "I recognized suddenly that it didn't smell like pork stew and sweat in this neighbourhood. And there weren't any loud voices and quarrelling." (182)

While in Andersson's and Alakoski's novels it is the neighbourhood's smells and noises that mark it as a deprived and shabby area, Eija Hetekivi Olsson's novel highlights the problem of architecture even more. The novel is set in a fictional Gardsten, which refers to the realworld Gårdsten, a poor multicultural suburb in Gothenburg, Sweden's second-biggest city. It is based in the 1980s and told from the perspective of Miira, a tough girl of Finnish descent. Miira is not the novel's first-person narrator, but the narrative is internally focalized around her throughout.

The housing complex Miira lives in is described as a desolate place. Although the streets are named after exotic spices- "Pepper Street, Thyme Street, Saffron Street, Nutmeg Street and Sage Street" (Hetekivi Olsson 14)-the dominating material, here, as in Svinalängorna and Vad det bra så?, is concrete: "Spices and concrete and high-rise after high-rise" (14). More explicit than the other two novels, Hetekivi Olsson's novel focuses on urban deprivation, particularly with regard to the school building. This is described as a flat, ugly brown building and the yard is depicted as deprived of any playground apparatus, with an asphalted ground, run-down and devastated not only by time but also by violently destructive kids who, for example, dig holes to 
make the grown-ups stumble and fall (9). Invasive destructiveness and vandalism are highlighted here as constituent parts of the suburban neighbourhood.

Another highly interesting representation of a school building is to be found in Mikael Niemi's novel Skjut apelsinen. The nameless male young protagonist who is the novel's first-person narrator, describes his school as follows: "This school is completely dead. Nothing but a burial chamber. How the heck do people stand it? They trudge along, they mumble and stare, their faces are grey, flabby and sluggish" (38). The school building is used here as a metaphor not only for the Swedish education system but for life as such. Life is described in architectural terms: “ . . . a long corridor with flickering fluorescent tubes and bare concrete walls, no windows, only year after year of stagnant air with regular stations" (38). And the people living such a life are consequently called "corridor crawlers" (39).

The exact nature of these "regular stations" (38) is not made clear in the novel. Drawing on Judith Halberstam, however, who has stressed the fact that most heterosexuals follow "a middle-class logic of reproductive temporality" (4), that is a life determined "by the conventions of family, inheritance, and child rearing" (2), we can read this passage as the young protagonist's clear criticism of conventional heterosexual life and an implicit plea for, as Halberstam puts it, a "queer "way of life" (1) that "can be imagined according to the logics that lie outside of those paradigmatic markers of life experience-namely, birth, marriage, reproduction, and death" (2).

The atmosphere of monotony and spatial narrowness and the resulting feeling of being trapped are characteristic of all literary places of secondariness presented in the novels in question. Pre-fabricated and standardized residential areas, so plentifully built in Sweden in the 1960s and 1970s, are presented in the novels as restricting the protagonists' possibilities to inhabit the city in an individual way. The fictional protagonists criticize that there are no places particularly designed for them, where they could gain experiences without being watched and controlled by adults. Hetekivi Olsson's Miira even goes so far as to directly blame the prime minister, Olof Palme, for the neighbourhood's non-existent, run-down or closed youth clubs. While the young people have to gather on the streets, she attacks Palme for sitting "in one of Stockholm's luxury restaurants and having luxury dinner with his politician mates" (171). Yet it is precisely the lack of "a room for themselves" that 
encourages the youth to occupy urban (non-)places and make them their own, whether this means a stuffy basement room, as in Låt den rätte komma in, or a forgotten bunker in the city forest, as in Skjut apelsinen.

We can detect a similar ambivalence when we examine the protagonists' feelings and emotions. On the one hand, the cities' deficiencies and pervading drabness are reflected in the protagonists' mood of frustration and pent-up anger. On the other hand, however, and in contrast to the prologue in Lena Andersson's novel, where frustration and a resulting propensity to violence were presented as a general consequence of the Swedish Million Programme, in this instance the various protagonists' perspective is more specific. Johan Ajvide Lindqvist's protagonist Oscar lets his frustration out by imagining himself a serial killer. Moodysson's Elin is also driven by violent fantasies. Half-crazed with boredom, she suggests robbing a pensioner and comes up with the idea of going to a party and setting the house on fire. Alakoski's Leena starts obsessive swim training, and the nameless protagonist in Niemi's novel starts writing aggressive poems to let off steam.

This last example is particularly interesting, as it shows clearly that not only is the body affected by the urban places, but so are the places by the bodies. In Skjut apelsinen, the protagonist leaves home at night and sprays his poem on the school wall. The effect is outstanding. In the eyes of the enthusiastic protagonist the defaced school building looks like a wounded whale. The words, sprayed onto the wall, have been inscribed into the concrete as into flesh. The building is bleeding, doomed to die. In youthful exuberance, the protagonist cries out:

The school was defeated, and I stood there together with hundreds of other pupils and read: Bomb the shit. Bomb the brains . . . It was a revolution. The souls had opened, people felt hope again, even anger, and joy and hatred, mystery, astonishment, irritation. They felt. They awoke. Someone had torn off the sticker, which covered the world, and beneath it reality turned up. Life. Everyone started to live again. (144)

The young protagonist's revolutionary attitude and the society's riotous future that is announced here, should not be taken too literally, of course. We are not dealing with an objective representation of reality, but with the character's subjective experiences; not with the presentation of objective space thus, but of lived space. This holds also true for all the other depictions of suburban living conditions and small-town atmosphere. 
The protagonists we are told about are children and teenagers who feel stuck in the place where they are growing up. Their perception of their surroundings is a subjective one and may thus exaggerate the places' awfulness. Compared with the far less successful story of public housing in, for instance, the UK, France and the USA in the second half of the twentieth century, the housing standards in Swedish public housing as implemented in the 1960s and 1970s can be regarded as quite high (Castell 2010). But even if Sweden here performs relatively well compared to other countries, this does not question the representation of Swedish places of secondariness as boring, restrictive, provincial and heteronormative. As literary depictions of nonmetropolitan identity formation, the novels give us a subjective but nonetheless nuanced picture of oftenoverlooked places of secondariness. The next passage will further elaborate on this point by focussing on the relation of spatiality and sexuality.

\section{Spatial and Sexual ( Re)Orientation}

The feeling that one has to fight against the town one lives in, to shatter entrenched structures and established patterns of behaviour, is also dominant when it comes to the realm of desire and sexual identity. Lukas Moodyson's movie Fucking Amål makes this particularly obvious. According to Moodysson's Elin, Åmål's stuffiness results from its utter uneventfulness. Everything seems controllable, predictable and highly static. There is no hope of discovering anything new, let alone extraordinary or sensational. Elin desperately calls out: "Aaahh! Why do we have to live in fucking bloody prick-Åmål!”

Elin's reference to Åmål as "fucking bloody prick-Åmål” reveals more about Åmål than its status as a boring town. It explicitly links spatiality and sexuality and elucidates male-dominated sexual norms as restricting. Swedish literary scholar Sven Hansell expands on this link and sees it as a marker for the city's confining patriarchal and heteronormative standards: "This place in Sweden, symbolically structured by the phallus, is no place for her to live in-the heterosexual norm is hegemonic and homophobia is ubiquitous in the small town" (103). Hansell's thesis basically also holds true for the other texts. Even though homophobia is less central in some of them, heteronormativity is a dominant factor in all the novels in question.

In Alakoski's Svinalängorna and Hetekivi Olsson's Ingenbarnsland, the main characters are girls who, from an early age, are seen and 
touched as sexual bodies. No one helps them to break this patriarchal legacy, not even their mothers. When Alakoski's Leena, for example, complains about sexual harassment by one of her father's friends, her mother tells her simply to ignore it. "She said I should just try to let it drip off" (46). But being touched like this will have a lasting effect on the body. You cannot simply let it drip off. The touch remains and unfolds, as Sara Ahmed has shown, as a second skin.

Reading Hetekivi Olsson's Ingenbarnsland, this process of sexual inscription becomes even more obvious. When Miira becomes a teenager, the neighbourhood's men start leering at her. Recognizing in herself the object of male desire, Miira reacts ambivalently. When her father's friends describe her lips as made for kissing she reacts furiously, swearing in Finnish: "Painu vittuun, fuck off" (23). But then she retracts her lips into her body, making them indiscernible. Some years later it is her breasts that arouse male desire. Again, it is one of her father's friends who comments on her body: "Look, now her tits start swelling" (83). Miira feels embarrassed. She runs into her room, shuts the door and tries to press back her small breasts into her body with an ice-cold spoon. The next day she pejoratively terms her breasts "fat balls" and tries to hide them from other people's gaze.

Miira experiences heterosexual desire as intruding and violating. But it nevertheless makes the girl's own desire straight. It is formed according to the heterosexual expectations with which she has been confronted throughout her life. Instead of looking for sexual alternatives, at the end of the novel Miira follows the heterosexual path and falls in love with a young man who has given her a tape by the rock band Yes, asking her to listen to the song "Love Will Find a Way"-without question a heterosexual way.

Other texts in my corpus, however, question the apparent normalcy of the "straight path." Oscar, the protagonist of Let the Right One In, for example, falls in love with a sexually highly ambivalent vampire. Alakoski's Leena, on the other hand, gets very close to her female friends. And Niemi's protagonist dresses in his mum's old and ugly cleaning smock and challenges people to call him gay, while he himself keeps "a straight face" (26). The protagonists' bodies are thus not necessarily "passive victim[s] of top-down processes of cultural inscription," as Jonathan Hale stresses by referring to Merleau-Ponty's concept of the "body-scheme." On the contrary, their bodies are "the means by which the individual can fight back against the forces of social and political domination" (Hale 28). 
The most prominent example of spatial and sexual reorientation, however, is to be found in Fucking Amål. The reorientation starts when Elin contravenes her mother's prohibition to leave the house at night and illicitly makes her way to Agnes, who is supposed to be a lesbian. Elin, first out of boredom and curiosity, later very consciously, expands her scope of activities beyond the town's beaten paths. By doing so she is able to re-orientate herself spatially as well as sexually. With Sara Ahmed's notion of the "contact zone" in mind (Queer Phenomenology 105), Elin's deviation from the expected line of heterosexual desire is far from self-evident. According to Ahmed, a contact zone is a place where women can come into contact with other women desiring women. They have to come close to each other to extend their bodies as no longer heterosexually restricted. Such a contact zone is not easy to find in a small town like Åmål that is structured by male dominance. Scholars like Gareth Griffith who play down the role of the film's specific setting are thus, putting it quite bluntly, wrong. Griffith states that

it doesn't matter at all if you happen to live in Åmål, in Mariefred, in Stockholm or anywhere. And that's why Agnes never blames Åmål for her misery. What keeps one from being oneself is not a place but a state of mind, so it's the state of mind and not the place that one has to get out of. $(149-50)$

Elin knows it better. The "state of mind" is closely linked to the place one lives in. Elin has bodily experienced Åmål as a town where your life's direction is determined in a very specific, namely heteronormative way. Close to Agnes, standing on a bridge that signals a way out, she dares to admit:

... I don't want to be like everyone else. Though sometimes I'm just the same . . . You know what my nightmare is? That I'll stay in Åmål. That I'll never move from here. I'll get kids, a car, a house . . . All of that. Then my husband leaves with someone younger and more beautiful and I'm stuck with kids that just scream and nag. It's so fucking meaningless. (Moodysson 84)

Very clear-sighted, Elin also sees the restrictions Agnes is subjected to. She cries out: “It's just because you live in fucking Åmål. It's so unfair. If you lived in Stockholm, for example, then you could have loads of girls" (84). As a consequence of this knowledge, Elin tries to make 
a radical change of direction. Instead of following the heterosexual path and going to a boy's party, she persuades Agnes to hitch-hike to Stockholm-the imagined city of free lesbian love. Stenport highlights: "The highway to Stockholm triggers fantasies of an alternative to smalltown limitations and heteronormative confinement" (45). The girls' escape to Stockholm, however, fails. They first have to experience the feeling of giddiness and nausea Merleau-Ponty has written about, before they finally are able to direct their desire to each other. In the film's grand finale they come out of the closet and announce their love publicly. "Ta-dam! Here I am. Here is my new girl! Do you mind moving your ass? We would like to fuck!" (Moodysson 161).

Self-confident and proud, the girls present themselves as a homosexual couple in a small town and claim to re-inhabit space as it fits for them. The point Lydia Wistisen makes with regard to another literary (heterosexual) young adult couple that transfers "physical limits and obstructions in public space in order to interfere with society's moral codes" (208), holds also true for our gay couple. After the two girls' spatial and sexual reorientation, they finally expect the town and its inhabitants to open for a broader variety of ways of living and loving.

Summing up, it can be said that the readings of the selected literary texts have shown that all characters are presented as particularly spacebound. They feel strongly marked by their cities' limited size that they experience as a certain kind of locale and provincial narrow-mindedness. The feeling dominant in their lives is the feeling of entrapment, of being spatially, socially and sexually "streamlined," stuck in an uneventful life, unfolding along the socially expected straight path. Niemi's nameless protagonist creates the metaphorically precise term "corridor crawler" to express this feeling.

But at the same time, the protagonists also give the reader a lively impression of how alternative ways of living are possible. Wandering around in the suburb or in the small town, they all find their individual way of life. While the extradiegetic narrators mostly refer to stereotyped second city images, the protagonists' movements through their (sub) urban environment modify and variegate these well-known pictures. Equipped with the sense of sight as well as those of smell, touch and hearing, they experience the places they inhabit in their full specificity. Even if the fictive narrators' perceptions should not be taken as straightforward evidence for how a certain place actually is or was, they surely give us a lively impression of embodied places of secondariness. 


\section{Notes}

1. Unless otherwise stated, all translation from Swedish to English are my own.

2. Moodyson's film and Lindqvist's novel have been translated into English. In my article, however, I will use the original Swedish titles when referring to these works.

3. Before Ahmed took up the concept of the second skin, it had been prominently discussed by Jay Posser. In Posser's 1998 book Second Skins: The Body Narratives of Transsexuality, he uses the term to describe transsexuality as a kind of transformative journey from one location to the other or from one skin to the other.

\section{Works Cited}

Abraham, Julie. Metropolitan Lovers: The Homosexualities of Cities. University of Minnesota Press, 2009.

Ahmed, Sara. Queer Phenomenology: Orientations, Objects, Others. Duke University Press, 2006.

Ahmed, Sara. "A Phenomenology of Whiteness." Feminist Theory, vol. 8, no. 2, 2007, 149-68.

Ahmed, Sara, and Jackie Stacey. "Introduction: Dermographies." Thinking Through the Skin, edited by Sara Ahmed and Jackie Stacey, Routledge, 2001, pp. 1-17.

Alakoski, Susanna. Svinalängorna. 2006. Bonniers, 2010.

Anderson, Lena. Var det bra så? Natur \& Kultur, 1999.

Björklund, Jenny. "Queering the Small Town: Lukas Moodysson's Film Show Me Love." Women's Studies, vol. 39, no. 1, 2010, pp. 37-51.

Castell, Pål. "The Swedish Suburb as Myth and Reality." Managing Yard and Togetherness: Living Conditions and Social Robustness through Tenant Involvement in Open Space Management. Chalmers University of Technology, 2010, www.publications.lib.chalmers.se/records/fulltext/local_122741.pdf. Accessed 4 February 2017.

Colombino, Laura. Spatial Politics in Contemporary London Literature: Writing Architecture and the Body. Routledge, 2013.

El-Bizri, Nader. "Being at Home among Things: Heidegger's Reflections on Dwelling." Environment, Space, Place, vol. 3, no. 1, 2011, pp. 47-71.

Ernst, Tony. "The Latin Kings: Svenska hjärtan." The Latin Kings: Texter. Ruin förlag, 2004, pp. 125-34.

Fanon, Frantz. Black Skin, White Masks. 1952. Grove Press, 2008.

Griffith, Gareth. "An Åmål State of Mind." City + Cinema: Essays on the Specificity of Location in Film. Edited by Gareth Griffith and Minna Chudoba, Tampere University of Technology, 2007, www.academia.edu/12626126/ An_Åmål_State_of_Mind. Accessed 4 February 2017. 
Halberstam, Judith. In a Queer Time and Place: Transgender Bodies, Subcultural Lives. New York University Press, 2005.

Hale, Jonathan. "Critical Phenomenology: Architecture and Embodiment." Architecture and Ideas, vol. 12, 2013, pp. 18-37. www.academia. edu/6234173/Critical_Phenomenology_Architecture_and_Embodiment. Accessed 4 February 2017.

Hall, Thomas, and Sonja Vidén. "The Million Homes Programme: A Review of the Great Swedish Planning Project.” Planning Perspectives, vol. 20, no. 3, 2005, pp. 301-28. doi:10.1080/02665430500130233.

Hansell, Sven. “-Du är inte normal! Kön, norm och frihet i Lukas Moodyssons filmer." Kvinnovetenskaplig tidskrift, vol. 25, nos 1-2, 2004, pp. 99-112. www.ojs.ub.gu.se/ojs/index.php/tgv/article/view/2306/2060. Accessed 4 February 2017.

Hedling, Erik. "The Welfare State Depicted: Post-Utopian Landscapes in Ingmar Bergman's Films." Ingmar Bergman Revisited: Performance, Cinema, and the Arts, edited by Maaret Koskinen, Wallflower, 2008, pp. 180-93.

Hetekivi Olsson, Eija. Ingenbarnsland. Norstedts, 2011.

Lefebvre, Henri. The Production of Space. 1974. Blackwell, 1991.

Lindqvist, Johan Ajvide. Låt den rätte komma in. 2004. Ordfront, 2010.

Merleau-Ponty, Maurice. Phenomenology of Perception. 1945. Translated by Donald A. Landes, Routledge, 2014.

Moodysson, Lukas. Fucking Åmål: Manuskript. Bokförlaget DN, 1999.

Molina, Irene. Stadens rasifiering: Etnisk boendesegregation $i$ folkhemmet. Kulturgeografiska institutionen, 1997.

Niemi, Mikael. Skjut apelsinen. Rabén \& Sjögren, 2010.

Pallasmaa, Juhani. The Eyes of the Skin: Architecture and the Senses. 1996. Wiley, 2012.

Posser, Jay. Second Skins. The Body Narratives of Transsexuality. Columbia University Press, 1998.

Stenport, Anna Westerståhl. Lukas Moodysson's Show Me Love. University of Washington Press, 2012.

The Latin Kings. Texter. Ruin förlag, 2004.

Tilton, Tim. The Political Theory of Swedish Social Democracy: Through the Welfare State to Socialism. Clarendon Press, 1990.

Wirth-Nesher, Hana. City Codes: Reading the Modern Urban Novel. Cambridge University Press, 1996.

Wistisen, Lydia. "From Windowsill to Underpass: Young Women's Spatial Orientation in Swedish Young Adult Literature." Literature and the Peripheral City, edited by Lieven Ameel et al., Palgrave Macmillan, 2015, pp. 198-214. 